\title{
O MAGMATISMO GRANITÓIDE DAS REGIÕES DE DOBRAMENTO NORDESTE E SUDESTE DO BRASIL
}

\author{
EBERHARD WERNICK*
}

\begin{abstract}
The granitoid magmatism of the Northeastern and Southeastern Foldregions, generated during the Brazilian Cycle $(1.000-450 \mathrm{~m} . \mathrm{y}$.) is described. The Foldregions are of ensialic nature, apparently with a "in situ" development and were submitted to a low-to medium pressure metamorphism. Geosutures and numerous major faults has been created and or reactivated during the entire history of these mobile areas.

One of the main characteristics of the Foldregions is their richness in granitoids, either in areal expression or in the very large number of bodies. They can be assembled in three main groups: 1 - Syntectonic group $(650 \pm 30 \mathrm{~m} . \mathrm{y}$.) including an autochtonous anatexites suite, an autochtonous to parautochtonous diororite-porphyroid granite suite, and a mobile tonalitegranite suite including porphyroid and equigranular bodies. 2 - Late tectonic group $(540 \pm 25$ m.y.), including a tonalite-granite, a monzonite-adamelite and an alkaligranite-syenite suite, but possibly also including alkaligabbros. 3 - Postectonic group $(510-460 \mathrm{~m} . \mathrm{y}$.) including plutonic rocks of calc-alkaline, subalkaline and alkaline nature and an eruptive-dyke calcalkaline suite with basalts, andesites, dacites and rhyolites. In some places, however, it is impossible to make a clear distinction between the late-and postectonic groups.

The origin of the syn-and late tectonic suites is linked with repeated anatexis at different crustal levels. The postectonic suites has been generated by anatexis of the lower part of the crust near the interfacies, with the mantle with major or minor contributions of juvenil material or by differentiation of basic juvenil magmas.

The syntectonic suites are of wet nature: the latetectonic group includs wet and dry suites and the postectonic suites are mostly dry. Related to the wet suites several mineral provinces with $\mathrm{Sn}, \mathrm{W}, \mathrm{Ta}, \mathrm{Be}, \mathrm{Li}, \mathrm{F}, \mathrm{Mo}$, etc., occur in skarns, pegmatites, greisens or quartz veins.

Many granitoid bodies are of polyphasic character with two or more different tectonic, structural, chronological, textural, petrographic or chemical portions, leaving to the development of highly heterogeneous complexes. The younger intrusions cuting or surrounding the older ones, induced in these more or less intensive phenomena of remobilization, recrystallizations, greisenfication and metassomatism, which result in strong age determination problems. The polyphasic nature, together with a strong structural control of the distribution and localization of the bodies from the different suites, pointed to the existense of many thermal focuses with continuous or intermitent activity during the whole evolution of the Foldregions and that the main tectonic lineaments has acted as thermal channels, along which the different phases of granitogenesis has taken place and which also controled the rising of the resulting magmas to the different crustal levels. In this way the magmatism show a clear affinity to border zones of larger structural elements which compose the Foldregions.

The general features of granitoid magmatism of the Northeastern and Southeastern Foldregion show many similarities with that of other mobile areas of ensialic nature.
\end{abstract}

INTRODUC̣ÃO Uma das mais destacadas feições das Regiões de Dobramento Nordeste e Sudeste é dada pela grande distribuição areal, pelo número e tipos de seus corpos granitóides. Este fato chamou, há longa data, a atenção dos mais diversos pesquisadores, não só em função de sua problemática geológica, estrutural, petrográfica e petrológica (genética), mas também devido aos recursos minerais que freqüentemente a eles se associam, constituindo várias províncias metalogênicas mais ou menos definidas.
Com o acúmulo progressivo dos dados disponíveis, alguns ensaios de síntese já foram elaborados, destacando-se, entre outros, para a Região de Dobramento Sudeste, os trabalhos de Fuck et al. (1967); Hasui e Hama (1972); Hasui e Sadowski (1976); Wernick e Penalva (1978 a, b); Hasui et al. (1978) e Sartori (1978) enquanto que para a Região de Dobramento Nordeste pontificam os trabalhos de Almeida et al. (1967); Brito Neves e Pessoa (1974); Brito Neves

\footnotetext{
* Departamento de Mineralogia e Recursos Minerais, Instituto de Geociências e Ciências Exatas - "Campus" de Rio Claro - Universidade Estadual Paulista "Júlio de Mesquita Filho" - UNESP - Caixa Postal, 178 - 13500 - RIO CLARO (SP)
} 
(1975) e Santos e Melo (1978), ou ainda de caráter geral Guimarães (1961).

O escopo do presente trabalho é uma tentativa de síntese do magmatismo granitóide de ambas as regiões de dobramento em foco. Pela ausência, muitas vezes, de dados mais específicos e de detalhe, por sua dispersão e heterogeneidade em função dos diferentes aspectos e locais de abordagem dos granitóides estudados, forçosamente o presente trabalho terá caráter genérico, necessitando várias das hipóteses e conclusões nele contidas de confirmações posteriores.

AS REGIÕES DE DOBRAMENTO NORDESTE E SUDESTE Após a sua consolidação ao fim do Ciclo Transamazônico $(2.0 \pm 0,2$ b.a. $)$, a extensa Protoplataforma Sulamericana sofreu, no Pré Cambriano Superior, importantes fenômenos de reativação (Amaral, 1974; Almeida 1978) que foram mais ativos entre 1800 e 1400 m.a., mas que perduraram até cerca de 1000 m.a. de anos atrás. A partir de então (no Ciclo Brasiliano) passaram a manifestar intensos fenômenos de regeneração tecto-orogênica, dos quais resultaram a implantação e evolução de 4 Regiões de Dobramentos (Nordeste, Sudeste, Central e Centro-Oeste), Hasui, et al. (1978), (Fig. 1). A estruturação das regiões de dobramento inclui, como elementos básicos, Faixas de Dobramento e Maciços Medianos. Estes são mais frequientes nas Regiões de Dobramento Nordeste e Sudeste, onde os cratons (entre os quais as Regiões de Dobramento se localizam) guardam maiores distâncias entre si (Fig. 1).

As Faixas de Dobramento são constituídas predominantemente por metassedimentos. Podem ser classificados, em alguns casos, de proximais e distais em relação aos cratons que delimitam as Regiões de Dobramento. Nas rochas dos sistemas proximais (ou exteriores) onde predominam ectinitos da fáceis dos xistos verdes, observa-se geralmente apenas uma fase regional de dobramento e seus sedimentos progradam sobre os cratons adjacentes sob forma de coberturas progressivamente menos deformadas e metamorfizadas no sentido do interior dos cratons. Janelas contidas nestas coberturas expõem localmente o embasamento metamórfico pré-brasiliano. Nos sistemas distais (ou interiores), as rochas pertencem às fáceis dos xistos verdes e do anfibolito, sendo freqüentes fenômenos anatecticos nas camadas basais, tornando dificultosa a sua separação do embasamento pré-brasiliano. Nas faixas interiores, é comum a ocorrência de duas fases regionais de deformação resultando em estruturas de caráter antiforme de porte diversos (megassinclinórios, meganticlinórios, anticlinórios, sinclinórios, sinclinais e anticlinais). Os meganticlinórios correspondem a geanticlíneos e, às vezes, neles chega a se expor o embasamento metamórfico pré-brasiliano.

Os Maciços Medianos têm dimensões e formas variáveis. São blocos crustais siálicos de complexa história evolutiva, podendo incluir rochas do Arqueano Inferior (Ciclo Guriense), Arqueano Superior (Ciclo
Jequié), Proterozóico Inferior (Ciclo Transamazônico) e do Proterozóico Superior (Ciclos Uruaçuano e Brasiliano). O seu grau de remobilização no Ciclo Brasiliano foi mais ou menos intenso. Muito influenciou a configuração areal das Faixas de Dobramento que as contornam (e.g. Maciço Pernambuco-Alagoas, $\mathbf{R}$. D. Nordeste, Fig. 2). Em termos lito-estratigráficos, é possível se estabelecer paralelos entre as unidades prébrasilianas nos Maciços Medianos com as dos Cratons adjacentes, conforme evidenciam datações radiométricas (Brito Neves e Cordani, 1973). Em termos estruturais, também parece haver uma correlação, apesar das deformações impostas pelos eventos brasilianos (Brito Neves, 1975). Assim as estruturas meridionais do Craton do São Francisco parecem indicar continuidade através da R.D. Nordeste, com inflexão geral para NE. Do outro lado estão a indicar persistência pela R.D. Sudeste, através do leste brasileiro (Hasui et al., 1978-a). Metassedimentos migmatizados ou não aparecem como restos nos Maciços Medianos, notadamente em suas bordas (e. g. M.M. Joinvile, R.D. Sudeste; M.M. do Rio Piranhas, R.D. Nordeste, Fig. 2). Este fato, aliado à profusa exposição de granitóides brasilianos autoctones e parautoctones, indica que os Maciços Medianos se situaram em níveis profundos.

O limite entre as Faixas de Dobramentos e os Maciços Medianos nem sempre é fácil de ser estabelecido, seja pela presença dos metassedimentos acima mencionados, da existência de grandes batólitos granitóides junto às interfácies ou, ainda, em função de fenômenos anatecticos. Entretanto, na maioria dos casos, as regiões limitrofes são caracterizáveis por grandes falhamentos que separam os blocos estruturais distintos e retalham em profusão ambas as Regiôes de Dobramentos aqui focalizadas.

Baseado em vários estudos executados na Região de Dobramento Nordeste e Sudeste (Brito Neves, 1975; Hasui et al., 1975, 1978-a; Almeida et al., 1976, 1978; Melo, 1978; Ribeiro e Lichtenberg, 1978; Silva Filho et al., 1978), a sua evolução pode ser assim resumida (Hasui et al., 1978-a; Wernick et al., 1978):

A) Uma etapa inicial, desenvolvida entre $1.0 \mathrm{e}$ 0.7 b.a. Deslocamento ao longo de falhas profundas, permitindo uma diferenciação do embas. mento prébrasiliano em sulcos e rugas. Sedimentaçâo e discreto magmatismo básico pré-tectônico.

B) Etapa intermediária entre cerca de 0.7 e 0.6 b.a. Metamorfismo de baixa a média pressão, com migmatização e granitização dos níveis mais profundos das Faixas de Dobramento e remobilização nos Maciços Medianos. Intensa granitogênese polifásica. Deformação polifásica com uma ou mais fases de dobramento holomórfico e outras de caráter local, relacionadas a crenulações, intrusões e falhas. Soerguimento orogênico.

C) Etapa final, desenvolvida entre cerca 0.6 a 0.45 b.a. Instalação de antefossas e intrafossas que aloja- 


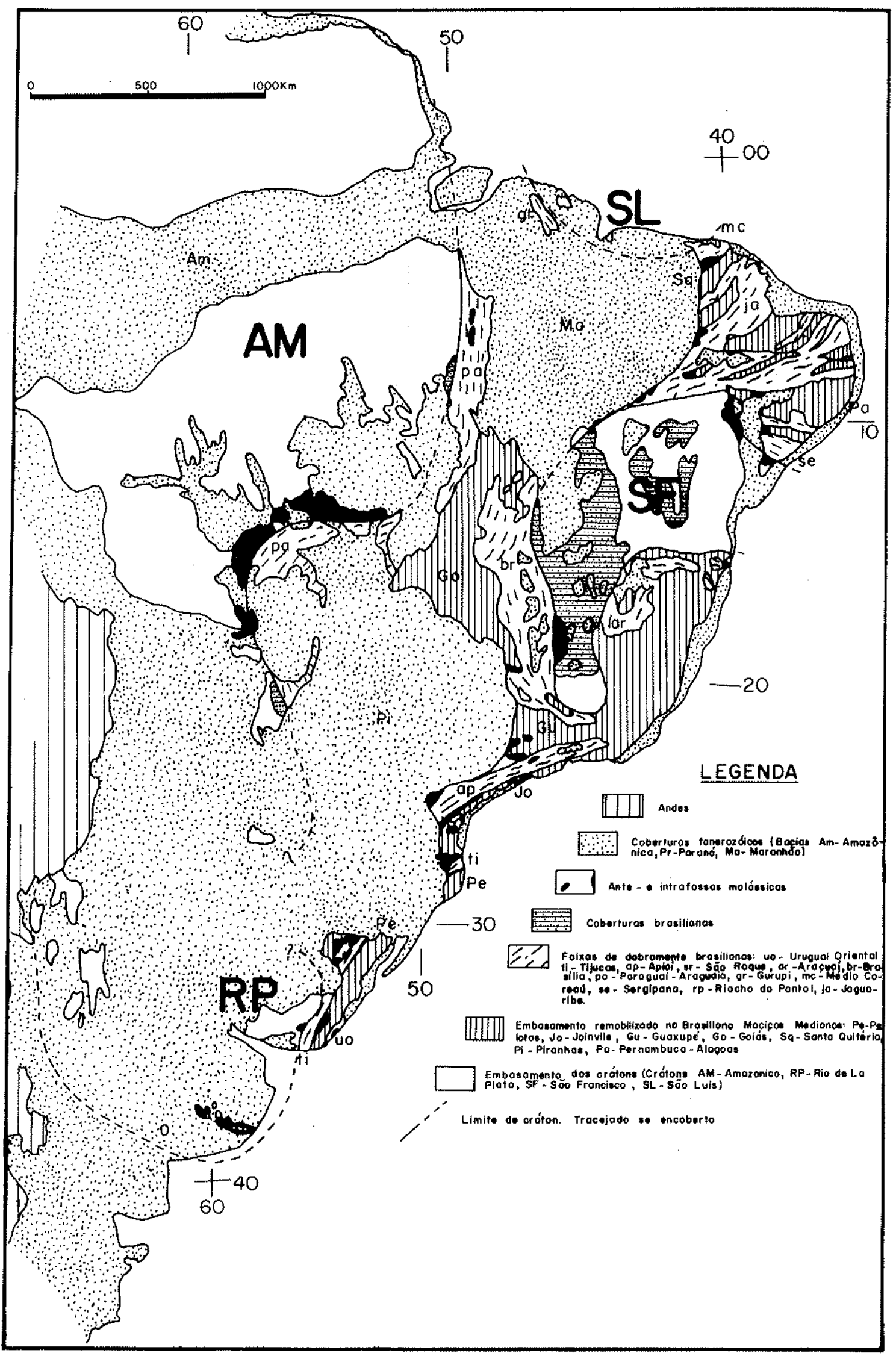

Figura 1 - As estruturas brasilianas (segundo Hasui et al, 1978a) 


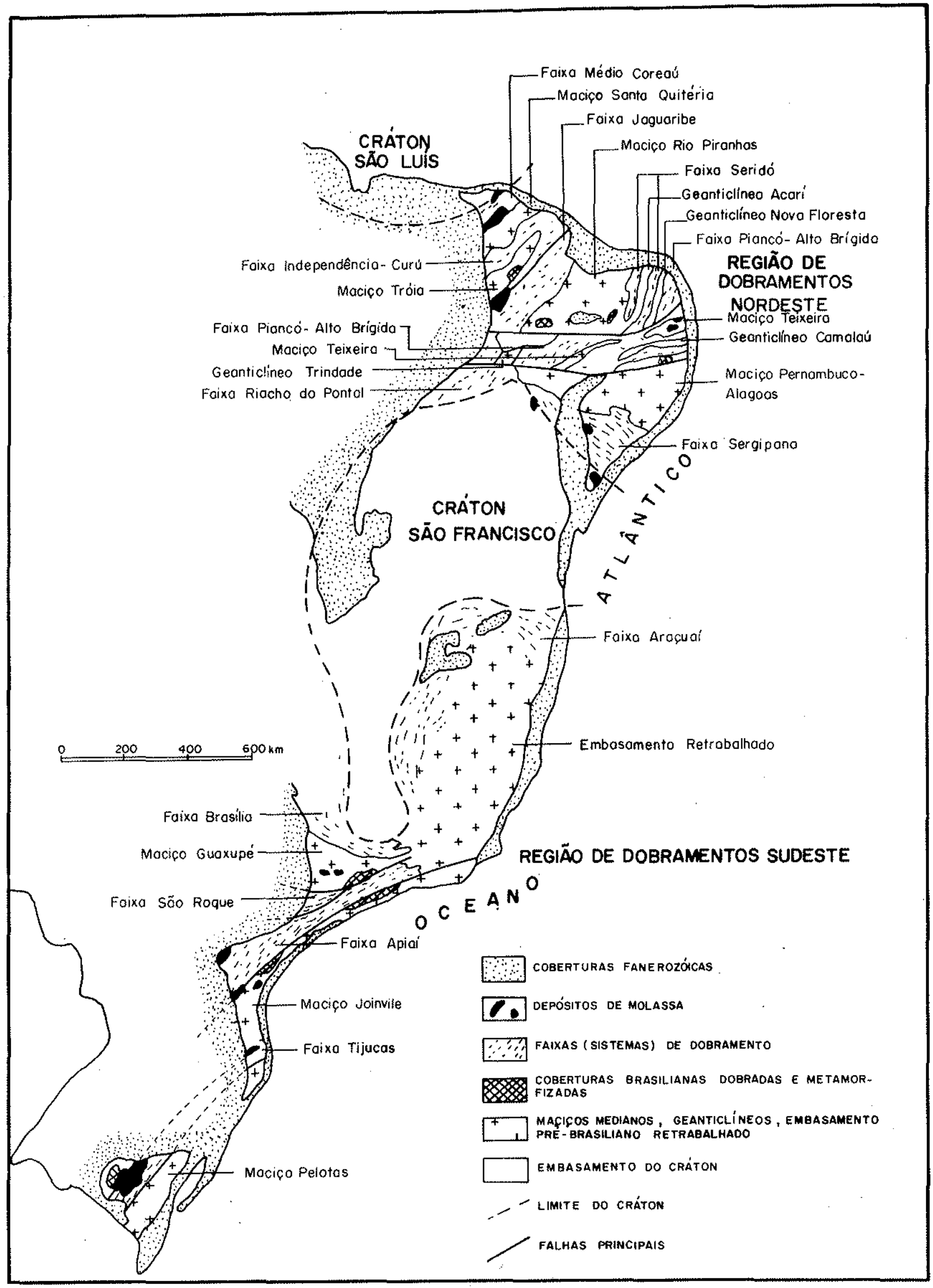

Figura 2 - As regiões de dobramentos Nordeste e Sudeste (segundo Wernick et al, 1978a) 
ram depósitos de melassa. Intrusões ácidas e derrames ácidos a básicos com intensidade variável. Intensa lineagênese em regime de falhas de transcorrência, resultando na configuração espacial atual das Regiões de Dobramento sob forma de blocos amendoados justapostos.

Segundo Wernick et al., 1978, a primeira fase ocorreu num regime tectônico tracional e as duas últimas em regime compressivo. Com o incremento da rigidez das rochas, na terceira etapa, os esforços compressivos resultam numa removimentação das falhas profundas em regime de transcorrência. Associado a estas transcorrências ocorrem distorções internas entre os blocos movimentados, resultando nas bacias molássicas e permitindo a ascensão das lavas a elas associadas, e o desenvolvimento de um magmatismo fissural com caráter regional.

Ao nivel atual dos conhecimentos, os mesmos autores sugerem para ambas as Regiões de Dobramento uma natureza ensiálica, e uma evolução "in situ", com predominância de movimentos verticais sobre os horizontais.

\section{CLASSIFICAÇÃO DE ROCHAS GRANITÓIDES}

De modo geral, as diferentes classificaçoes de rochas granitóides podem ser agrupadas em 6 grupos: 1 petrográficas (mineralógicas com ou sem aspectos texturais); 2 - estruturais; 3 -químicas ; 4 - posicionamento espacial; 5 - tectônicas, e 6 - genéticas. Os dois primeiros grupos geralmente são de caráter descritivo. $\mathrm{O}$ terceiro pode ser tanto classificativo $(e, g$. Nockolds, 1954, Iugs, 1973) quanto ter uma conotação genética-evolutiva. Os grupos 4 e 5 levam geralmente ao desenvolvimento de esquemas magmatogênicos que encontram a sua síntese no último grupo de classificação (e. g. Smulikowki, 1958; Middlemost, 1969). Menciona-se ainda um grupo especial de classificações resultantes de trabalhos experimentais (Tuttle e Bowen, 1958; Hall, 1971).

As classificações do grupo 4 ressaltam, via de regra, os níveis crustais dos granitóides e sua mobilidade relativa, caso dos esquemas de Read (1943), Raguin (1957), Buddington (1959), Hutchinson (1970), Thayer e Jackson (1972) e Stephannson (1975). Entretanto, em todos estes esquemas também transparecem nitidamente aspectos genéticos.

Um dos problemas destas classificações, reside no tempo de ascensão dos corpos mais móveis e o espaçamento temporal das diversas fases de deformação. Corpos móveis, formados num certo evento granitogênico, podem ou não sofrer deformações sucessivas por fases de deformação que ocorrem após a sua gênese, mas durante a sua ascensão rumo a níveis mesoe epizonais originando, assim, quanto à classificação tectônica, toda uma transição entre corpos sin- tardie pós-tectônicos em relação à deformação considerada, mas que, em realidade, estão ligados a apenas uma fase genética.
As classificações tectônicas (grupo 5) se baseiam, fundamentalmente, nas fases da evolução do ciclo orogênico, que inclui uma etapa geossinclinal, uma tectoorogênica e uma de transição. Geralmente, a granitogênese se mostra vinculada às duas últimas etapas (Muratov, 1968, 1977; Ustiyev, 1970). Deste esquema resultaram várias classificações, até certo ponto semelhantes entre si, caso das de Sederholm (1891), Scheumann (1924), Högbom (1928), Eskola (1932), Saksela (1936), Wahl (1936), Jung e Roque (1938), Roque (1941), Simonen (1960) e Marmo (1971), entre outros.

Este tipo de classificação encontra dificuldades de aplicação em área geossinclinais de estruturação complexa, onde os dobramentos atingem com defasagem temporal e espacial os seus diferentes segmentos (eu- e miogeossinclinais, e. g. Zaridze, 1975) ou mesmo para áreas geossinclinais com duas ou mais fases de dobramento regional. Neste caso, por exemplo, corpos sintectônicos à primeira fase são em realidade, pré-tectônicos às fases subseqüentes. Desta maneira, há a necessidade de caracterização de granitóides sin-, tardi- e pós-tectônicos para cada fase de dobramento, o que requer um conhecimento detalhado da evolução estrutural da área em foco. Esta problemática, tornase ainda mais complexa nos cinturões ou faixas móveis (mobile belts), submetida a sucessivas regeneraçoes e nas quais sequer é possível a caracterização plena das fases evolutivas do cinturão orogênico clássico fanerozóico.

Apesar da ausência de conhecimentos mais detalhados sobre a evolução estrutural das Regiões de Dobramento Nordeste e Sudeste, no presente trabalho será utilizada basicamente a classificação tectônica, mas sempre que necessário, para facilitar uma melhor visualização dos problemas abordados, também será utilizada a classificação baseada no posicionamento espacial

GRANITÓIDES DAS REGIÕES DE DOBRAMENTO NORDESTE E SUDESTE 1) Suite Sintectônica $(650 \pm 30$ m.a.) A suite sintectônica é a mais freqüente, em exposição areal, nas Regiões de Dobramento Nordeste e Sudeste, ocorrendo quase exclusivamente nos Maciços Medianos, nos Geanticlineos e em outras áreas de exposições das infraestruturas pré-brasilianas retrabalhadas sob elevadas condições térmicas durante o Ciclo Brasiliano. A suite inclui dois tipos de complexos granitóides: $\mathbf{A}$ - anatexíticos e $\mathbf{B}$ - granitos porfiróides.

A - Granitos Anatexíticos - São massas granitóides heterogêneas com estruturas acamadas, dobradas, schlieren, nebulíticas e menores porções de material homofânico. Constituem corpos de dimensões variáveis, desde pequenos, confinados aos núcleos de estruturas antiformes menores, até imensas massas batolíticas. São corpo-autoctones, cata- a mesozonais, que gradacionam lateralmente para gnaisses menos mobilizados e deformados. Frequientemente são alon- 
gados, se bem que não faltem corpos constituindo núcleos e manchas irregulares. No caso dos corpos alongados e suas estruturas principais são paralelas às das rochas encaixantes.

Os granitóides anatexíticos resultam da fusão parcial e remobilização mais ou menos intensa (diatexia, metatexia), quer das camadas metassedimentares basais brasilianas quer do embasamento pré-brasiliano. Como neste são comuns massas anatexíticas ligadas ao Ciclo Transamazônico, a sua distinção das formadas no Ciclo Brasiliano requer estudos petrográficos, estruturais, químicos e geocronológicos detalhados. Em função deste fato, o número de corpos granitóides anatecticos perfeitamente delimitados e caracterizados é ainda relativamente pequeno $(e . g$. Fuck et al., 1967; Santos, 1969; Melcher et al. 1973; Brito Neves e Pessoa, 1974: Brito Neves, 1975: Hasui e Sadowsky, 1976).

B - Granitos Porfiróides - São as rochas sintectônicas granitóides mais frequientes. Constituem corpos com dimensões variáveis, freqüentemente batolíticas. Ostentam feições estruturais, texturais, composicionais e posicionamento espacial (mobilidade) variáveis, o que permite o seu desmembramento em duas associações :

I - Associação Autoctone - Parautoctone, catazonal a mesozonal, incluindo rochas de granulação fina a média. Constituem complexos amplos, heterogêneos, com foliação marcante, paralela às das rochas encaixantes para as quais geralmente gradacionam continuamente. Comum são intercalações ou enclaves mais ou menos frequientes e possantes de rochas máficas representadas por gabros, meladioritos e quartzodioritos que têm sido interpretados por alguns autores (Brito Neves e Pessoa, 1974), como restos do magmatismo básico pré-tectônico.

A composição dos granitos porfiróides varia de diorítica a granítica, dependendo das proporções relativas de quartzo, oligoclásio e microclina. Biotita e hornblenda são os máficos mais comuns, tendo sido assinalada localmente também a presença de piroxênios. Feição comum é a ocorrência de megacristais de microclina com dimensões (até mais de $15 \mathrm{~cm}$ ), formas (retangulares, ovaladas, irregulares), disposição forientada, suborientada, caótica) e em quantidades variáveis inseridos numa mesma matriz predominantemente hipautomórfica granular, (Fuck et al., 1976; Wernick, 1972; Hasui, 1973; Sadowsky, 1974; Wernick e Gomes, 1976 e 1977; Melcher et al., 1973; Wernick et al., 1976; Wernick e Penalva, 1974, 1978-a, b). Localmente megacristais de oligoclásio também têm sido detectados (Sadowsky, 1974; Wernick e Penalva, 1978). As cores dos megacristais são cinza claras, esbranquiçadas ou rosadas - avermelhadas e, com o seu incremento nas rochas, estas, cujas matrizes são predominantemente cinza escuras, tornam-se mais claras.

Em função das dimensões e quantidades e do seu maior ou menor grau de orientação e da matriz, vá- rios tipos estruturais-texturais têm sido caracterizados (e. g. Almeida et al., 1967; Hasui e Hama, 1972; Brito Neves e Pessoa, 1974; Hasui et al., 1978-b), se bem que em corpos maiores seja comum a coexistência de vários dos tipos discriminados.

A origem desses megacristais tem sido muito discutida, sendo advogada tanto uma recristalização em condições subsólidas quanto uma gênese metassomática, muitas vezes com caráter recorrente (e.g. Picada, 1967; Coutinho, 1972; Wernick, 1972-a; Hasui, 1973; Wernick e Gomes, 1976; Gomes et al., 1976; Wernick et al., 1976; Kaul, 1976; Wernick, 1978; Wernick e Penalva, 1978-b; Krebs et al., 1978).

Tal discrepância resulta dos diversos corpos estudados pelos diferentes autores, ora de natureza autóctona-parautóctona, ora de caráter parautóctono-aloctono ou, ainda, francamente aloctóno. Sinais patentes de intensa granitização são atestados nos complexos autóctones, através da transformação de quartzo-dioritos e meladioritos em granodioritos ou de outras rochas mais básicas em sienitos porfiróides (e. g. Pessoa, 1972; Wernick e Penalva, 1972; Mello, 1971; Santos e Mello, 1978). Wernick (1972-a) e Wernick et al. (1976), mostraram o controle das estruturas regionais, locais e dos aspectos texturais e composicionais das rochas afetadas no desenvolvimento dos megacristais. A intensidade da granitização brasiliana foi ressaltada, para as Regiões de Dobramento Nordeste e Sudeste, por Ebert (1969), Santos (1968, 1969), Wernick e Penalva (1972), Wernick (1972-a), Hasui (1973), Sadowski (1974) e Brito Neves (1975), entre outros.

As rochas da associação porfiróide autóctona formam gigantescos complexos heterogêneos em áreas de gnaisses e anatexitos, em relação aos quais exibem contatos pouco nítidos e concordância estrutural. Apenas, localmente, são observados contatos nítidos, intrusivos, o que permite caracterizar partes de complexos maiores como parautóctones. Ocorrem nos Geanticlíneos, nos Maciços Medianos e no interior das Faixas de Dobramento, onde seu substrato pré-brasiliano, muito remobilizado durante o Ciclo Brasiliano, ora se acha exposto por ação erosiva fanerozóica (Almeida et al., 1978). A associação de granitos porfiróides sintectônicos, autóctones a localmente parautóctones, catazonal, foi denominada por Santos e Mello (1978) para a Região de Dobramento Nordeste de Associação de Raiz (ou Inferior) Diorito-Granito Porfiróide.

II - Associação Parautóctone-Aloctone - Apresenta a mesma filiação genética da associação anterior caracterizando-se, entretanto, por um maior grau de mobilidade, que permitiu a ascenção das massas granitóides a níveis mesozonais e mesmo epizonais. Os corpos ocorrem nos Maciços Medianos, nos Geanticlíneos e nas Faixas de Dobramento, sendo seu alojamento controlado por falhas, fraturas e estruturas antiformes. 'As rochas porfiróides desta associação são 
algo mais ácidas e os corpos são maì homogêneos, quer tanto à composição quer quanto à distribuição dos megacristais e à natureza da matriz, cuja tendência é se tornar mais isotrópica e hipautomórfica granular. No caso dos corpos alóctones ocorre o desenvolvimento da auréola de contato e frequientemente exibem ativa tectônica de borda, lineações marginais e sinclinais marginais, indicando tratar-se de intrusões forçadas ou diapíricas. Esta associação foi denominada, na Região de Dobramento Nordeste, de Associação Móvel (ou Superior) Tonalito-Granito (Santos e Melo, 1978).

A associação I e II pode ocorrer isolada ou associada. $\mathrm{O}$ quadro geológico verificado, depende do nível de erosão. Nos níveis intermediários é comum a coexistência entre ambas, com a Associação II cortando a Associação I ou constituindo manchas ou núcleos mais homogêneos no seu interior. Outras vezes, a Associação II constitui corpos vicinais, independentes e homogêneos, nas proximidades de complexos da Associação I. Nos níveis crustais superiores há amplo predomínio da Associação II, mas sua vinculação com a Associação I é atestada pela ocorrência de enclaves desta naquela. Neste nível, a Associação II origina corpos circunscritos que desenvolvem discreta auréola de contato.

A Associação II evidencia sinais de diferenciação para rochas equigranulares de composição tonalítica a granítica. Estes formam tanto manchas ou núcleos difusos nos corpos porfiróides; cortam-os sob forma de intrusões e corpos fissurais com dimensões variáveis, ou formam corpos vicinais isolados, que frequientemente rodeiam os corpos porfiróides maiores. Este processo de diferenciação foi examinado por Wernick (1978) na Província Ribeira (Estados de São Paulo e Paraná, R.D. Sudeste) baseado em elementos, traços e características texturais e evidenciada por meio de técnicas estatísticas (Landim et al., 1974), que revelaram a presença de corpos com zoneamento litológico mais ou menos discreto. Hasui e Hama (1972) ressaltam a conexão entre granitos porfiróides da Associação II e granitos turmałiníferos equigranulares no Estado de São Paulo. A vinculação entre granitos porfiróides e equigranulares é ressaltada também para a Região de Dobramento Nordeste (Santos e Melo, 1978), mas estes autores vinculam os granitos equigranulares a uma maior mobilização da Associação I e não aos granitóides porfiróides da Associação II. Feição geológica desta vinculação quer direta, quer indireta entre os granitos porfiróides da Associação I e Il, é a ocorrência generalizada de corpos equigranulares com enclaves de ambas as associações. Tanto os granitos porfiróides quanto os equigranulares da Associação II apresentam feições variáveis, desde quase sintectônicas até praticamente póstectônicas, já que sua ascenção, evolução progressiva (homogeinização e diferenciação) e intrusão final nos diversos níveis crustais está mais ou menos distancia- do, no tempo, de seu evento genético, ligado à etapa sintectônica.

Uma das características da Associação Il é a sua natureza hidratada. Esta se manifesta principalmente nos níveis mesozonais com o desenvolvimento de profusos pegmatitos, aplitos e veios de quartzo ao lado de fenômenos de greisenficação. A estes fenômenos estão associados importantes recursos minerais de natureza predominantemente litófila, incluindo W e Mo em escarnitos, $\mathrm{Ba}, \mathrm{Ta}, \mathrm{Cb}, \mathrm{Sn}$ e $\mathrm{Li}$ em pegmatitos e greisen e $\mathrm{Au}, \mathrm{Ba}, \mathrm{F}, \mathrm{Cu}, \mathrm{Pb}$, etc. em veios de quartzo (Santos, 1973; Pessoa, 1974; Brito Neves, 1975; Bettencourt et al., 1976; Sá, 1977; Wernick et al., 1978). Estas mineralizações constituem províncias mais ou menos definidas, caso das Províncias de Borborema, Salenópolis e Cristais na Região de Dobramento Nordeste e das Províncias Sul da Bahia-Rio Doce e Encruzilhada, entre outras, na Região de Dobramento Sudeste.

Outras vezes, os granitóides hidratados levam à formação de uma auréola migmatítica de espessura variável e nos quais é possível, em alguns casos, o reconhecimento de 3 zonas distintas: uma distal (ou externa) de migmatitos acamados; uma intermediária com migmatitos agmatíticos e de schollen e uma proximal (ou interna) com migmatitos dobrados, schllieren, nebulíticos e homofânicos que circunda a intrusão granítica central (Wernick e Penalva, 1978-a, b), conforme a Fig. 3.

2) A Suite Tarditectônica $(540 \pm 25$ m.a.) A suite tarditectônica tem sido descrita principalmente na Região de Dobramento Nordeste (Brito Neves e Pessoa, 1974; Brito Neves 1975; Santos e Melo, 1978), apesar da existência de rochas similares na Região de Dobramento Sudeste (Fuck et al., 1967; Coutinho, 1971; Melcher et al., 1973: Hasui e Hama, 1972; Carraro et al., 1974; Wernick e Penalva, 1978-a; Hasui et al., 1978-b; Sartori, 1978). Inclui corpos circulares a subcirculares, alguns corpos estratiformes e abundantes manifestações fissurais. Sua classificação como tarditectônica tem sido baseada em seu posicionamento espacial, caráter não-harmônico com contatos nítidos, desenvolvimento de auréolas de contato, freqüente associação com zonas de falhamento, quimismo, dados geocronológicos e por comparação com outros esquemas tecto-magmáticos existentes na literatura (Brito Neves e Pessoa, 1974).

A suite tarditectônica inclui principalmente 3 associações litológicas:

A) Associação Tonalito-Granito. A sua distinção dos produtos finais da diferenciação da Associação II é frequientemente difícil, sendo inclusive questionável se a associação constitui realmente um grupo de rochas tarditectônica. Inclui corpos predominantemente equigranulares com textura hipautomórfica a xenomórfica granular, fina a grosseira e compreende rochas de cores rosada a cinzenta. Plagioclásio, quart- 


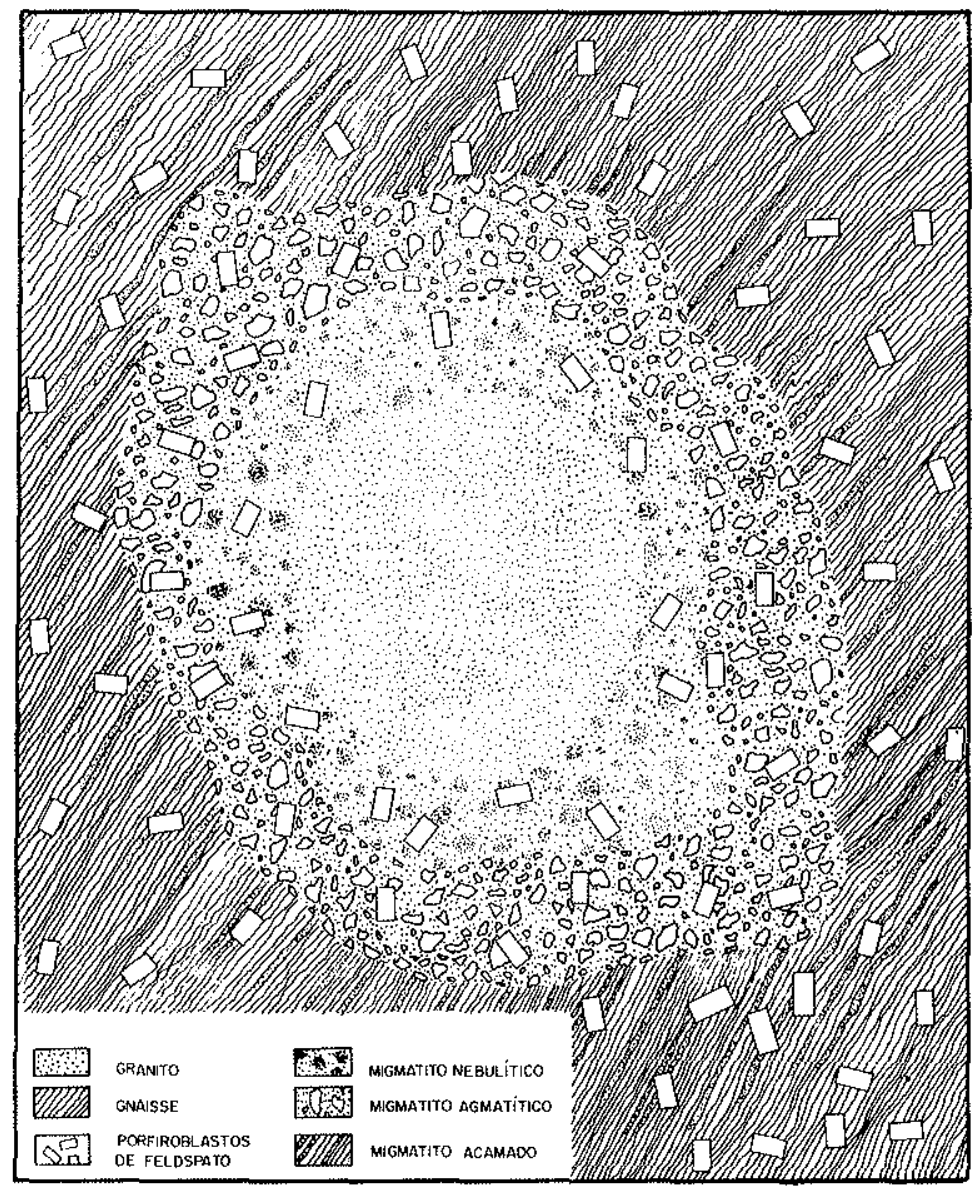

Figura 3 - Estrutura esquemática de uma auréola migmatítica

zo e microclina ocorrem em proporções variáveis. Os máficos das rochas leuco- a mesocráticas são a biotita e/ou a hornblenda. Alguns corpos mostram tendências subalcalinas com pobreza em máficos (biotita) e riqueza em plagioclásios bastante sódicos. Ocorrem tanto sob forma de pequenos stocks ou bossas circulares a subcirculares, associadas a zonas tectônicas ou formando diques de dimensões variáveis. Entre as várias descrições, destacam-se as de Almeida et al. (1967); Humphrey e Allard (1969); Santos (1971) e Brito Neves e Pessoa (1974).

B) Associação Monzonito-Adamelito. A associação inclui rochas pobres em sílica e álcalis. Constituem maciços estratiformes pequenos a médios, deformados, associados a faixas cataclásticas. Por ação da cataclase hedenbergita, sienodioritos ou monzonitos são transformados em ferro-hastingita adamelitos. A associação é nitidamente seca, pois pegmatitos e aplitos cogenéticos são muito raros. Na Região de Dobramento Nordeste, esta associação tem sido denominada de Associação Moderna (Santos 1971, 1977; Santos e Vasconcelos, 1973; Santos e Melo, 1978).

C) Associação Alcaligranito-Sienito. Inclui além de alcaligranitos com piroxênios (egirina ou egirinaaugita) e hornblenda (richterita) também quartzosie- nitos e sienitos ao lado de, possivelmente, gabros alcalinos (analcima e bogusitos). As intrusões, circulares ou ovaladas, estão ligadas a alinhamentos tectônicos e são acompanhadas de uma grande quantidade de rochas fissurais incluindo umptekitos, lindoitos, nordmakitos, shonkinitos, microsienitos, microdioritos e microgranitos. Localmente, fenomenos de fenetização e greinsenficação estão presentes. A ocorrência de intrusões sieníticas desta associação com xenolitos de monzodioritos, quartzomonzonitos, monzogranitos e granodioritos (Pessoa et al., 1978) parece indicar uma filiação temporal com as Associações A e B. Na Região de Dobramento Nordeste, esta associação tem sido denominada, genérica ou especificamente, de Associação Catingueira (Almeida et al., 1967, Brito Neves e Pessoa, 1974; Santos e Melo, 1978), enquanto entre as várias descrições, mais ou menos detalhadas, destacam-se as de Vandoros e Coutinho (1966); Ferreira (1967); Ferreira et al. (1969); Farina e Melo (1970); Brito Neves (1975); Sadowsky (1975) e Santos e Silva (1975).

3) A Suite Pós-Tectônica $(510-460$ m.a.) O plutonismo pós-tectônico é relativamente raro nas $\mathrm{Re}$ giões de Dobramento Nordeste e Sudeste quando considerado como filiado, temporalmente, à fase molás- 
sica (Brito Neves e Pessoa, 1974; Wernick e Penalva, 1976; Santos e Melo, 1978; Hasui et al., 1978-b). Em muitos casos, a sua distinção das manifestações tarditectônicas é bastante difícil, quando não ocorre relacionamento tectônico ou espacial nítido com a fase de implantação, sedimentação e magmatismo efusivo e fissural das bacias molássicas. Tais condições são relativamente raras, quer nos Maciços Medianos quer nas Faixas de Dobramento, servindo, neste caso, principalmente as datações geocronológicas para a determinação da natureza tectônica dos corpos. Em realidade, o que parece ocorrer é uma gradação temporal contínua entre a fase tardi- e pós-tectônica.

A suite pós-tectônica é constituída de duas associações:

1) Associação Plutônica. É representada por corpos circulares, arredondados, elíticos ou irregulares que ocorrem associados a falhas e fraturas. São de cor cinzenta, rosada ou vermelha, textura hipautomórfica ou xenomórfica granular, fina a grosseira, predominantemente equigranular, se bem que não faltem termos inequigranulares ou profiríticos. São granitóides de meso- a epizona ou mesmo subvulcânicos, atestada pela ocorrência, em alguns corpos, de grandes grãos de quartzo arredondados. São, via de regra, anidros, pobres em pegmatitos e aplitos, circunscritos, e desenvolvem discreta auréola de contato. Englobam corpos calco-alcalinos, subalcalinos (incluindo alcalinas potássicas) e alcalinas, representadas por granodioritos, granitos, alasquitos, monzogranitos, alcaligranitos, sienogranitos, e quartzomonzonitos. Muitos dos corpos são de composição complexa, coexistindo numerosas variedades petrográficas, inclusive com filiação 'química variada (Santos e Melo, 1978; Sial 1978; Sartori, 1978). Nas variedades alcalinas é comum a ocorrência de albita, ortoclásio pertítico, ferrohastingita e aegirina-augita.

2) Associação efusiva-fissural. As rochas plutônicas pós-tectônicas são acompanhadas de um amplo cotejo de rochas efusivas, piroclásticas e filonares com afinidade calco-alcalina, incluindo basaltos, andesitos, dacitos, riolitos, diabásios e granitos e granodioritos pórfiros. Parte das rochas mostram-se espelitizadas e queratofizadas (Wernick, 1972-b; Melcher et al., 1973).

\section{A COMPLEXIDADE DOS CORPOS GRANITÓI-} DES Uma das características dos corpos granitóides das Regiões de Dobramento Nordeste e Sudeste, frequientemente independente de sua natureza tectônica, posicionamento espacial ou mesmo de suas dimensões, é a sua grande complexidade. Esta caracteriza-se pela coexistência num corpo de duas ou mais fases com posicionamento espacial (e. $g$. frações autoctones, parautoctones e aloctones), tectônicos (sin-, tardi- e pós-tectônicas) texturais (equigranulares, inequigranulares, porfiríticas, porfiróides), petrográficas (calco-alcalinas, subalcalinas e alcalinas) ou geocro- nológicas diversas (Fuck et al., 1967; Wernick, 1972-a; Hasui, 1973; Rideg, 1974; Wernick e Penalva, 1978 a, 1978; Hasui e Sadowsky, 1976; Sartori, 1978; Sial, 1978; Pessoa et al., 1978, entre outros). Este fenômeno foi caracterizado por Wernick e Penalva (1978-a) como a formação de complexos polidiapíricos. A diferença entre este conceito e o polidiapirismo de Stephannson (1975), reside no fato dos complexos não serem formados somente por diápiros (isto é, várias intrusões que ascendem passivamente formando grandes complexos coalescentes), mas sim a produção de massas granitóides complexas e polifásicas, sem conotação quanto a sua mobilidade e envolvendo, sobretudo, um conceito de "telescoping" (e.g. granitos sintectônicos catazonais cortados por corpos tardi- e/ou pós-tectônicos meso-epizonais). A penetração de corpos mais jovens nos mais antigos, provoca nestes sinais, mais ou menos patentes de recristalização, remobilização, greisenficação e metassomáticos que dificultam as datações geocronológicas.

CONTROLE DO AlojAMENTO As Regiões de Dobramento Nordeste e Sudeste caracterizam-se em toda sua evolução por uma intensa e contínua lineagênese, quer pela criação de novos lineamentos tectônicos quer por sucessivas reativações de lineamentos pré-brasilianos e brasilianos (Wernick et al., 1978). Em realidade, o inicio desta lineagênese se iniciou após a consolidação da Protoplataforma Sulamericana, ao término do Ciclo Transamazônico (Almeida, 1978). A retomada destas direções no início do Ciclo Brasiliano, por volta de 1,0 b.a. atrás, propiciou a diferenciação do embasamento pré-brasiliano em calhas de sedimentação (as futuras Faixas de Dobramento) e altos do embasamento (os Maciços Medianos), de tal modo que estas grandes direções estruturais representam, freqüentemente, as zonas limítrofes atuais entre estes dois elementos tectônicos principais das Regiões de Dobramento.

A) Parte destas zonas tectônicas tinha natureza primária profunda, como atesta a existencia de um magmatismo básico pré-tectônico (derrames, sills, diques, intrusões e possíveis tufos), ora representados por anfibolitos, hornblenda-xistos e xistos verdes.

B) Os lineamentos continuaram ativos durante a etapa geossinclinal como atestam, nas calhas de sedimentação, diversos níveis de conglomerados.

C) E marcante a influência dos lineamentos na localização dos granitóides da etapa orogênica. Característica é a ocorrência de imensas massas batoliticas, quer ao longo quer nas proximidades da interfácie Maciços Medianos/Faixas de Dobramento, ou ao longo de outros grandes alinhamentos tectônicos. No primeiro caso incluem-se, entre outros, os complexos granitóides Encruzilhada e Pedras Grandes (Estados do Rio Grande do Sul e Santa Catarina, R.D. Sudeste, Fig. 4) e o complexo Piedade-Agudos Grandes situado no Maciço Mediano de Joinvile entre as Faixas 
de Dobramento São Roque e Açungui (Estados de São Paulo e Paraná, R.D. Sudeste, Fig. 2). Exemplo de massas granitóides, controladas através de linhas tectônicas cortando o embasamento pré-brasiliano, está representado no Estado do Rio de Janeiro (R.D. Sudeste, Fig. 5).

Baseado na influência dos grandes lineamentos na localização e distribuição dos granitóides na Região de Dobramento Nordeste, Santos e Melo (1978) caracterizam na mesma 4 províncias granitóides (Fig. 6). A Província Setentrional abrange magmatismo de pequena profundidade e um plutonismo cata-mesozonal, sendo particularmente clara a associação entre do primeiro tipo com grandes fraturas. A Província do Médio Ceará compreende um plutonismo mesozonal adjacente ao feixe de falhas que atravessa diagonalmente o Estado do Ceará (Mello et al., 1978). A Província Central abrange plutonismo cata- meso- e epizonal, visivelmente relacionado a um amplo feixe de falhas em sigma invertido que caracteriza a estruturação desta área. A Província Meridional engloba principalmente um plutonismo cata-mesozonal. Compartimentação semelhante foi estabelecida por Wernick e Penalva (1978-a) para o Sul do Brasil e por Hasui et al., (1978-b) para os Estados de São Paulo e Paraná.

D) A natureza profunda de parte destas falhas é atestada pela ocorrência ao longo das mesmas de granitos estaníferos (Skvor, 1967).

E) $\mathrm{Na}$ fase final e da passagem da etapa tectometamórfica para a etapa de transição, o que caracteriza um progressivo enrijecimento das rochas, ocorre a penetração da suite tarditectônica, freqüentemente controlada por falhas quer neoformadas quer reativadas. A existência de associações alcalinas parece indicar novamente a natureza profunda de vários destes alinhamentos tectônicos.

F) Já na etapa de transição com as rochas mais rígidas, mas ainda submetidas a um regime compressivo, ocorre uma intensa reativação das falhas préexistentes em regime de transcorrência.

Associada a transcorrência ocorrem distenções internas entre os blocos movimentados, resultando nas bacias molássicas tectônicas e permitindo a ascenção de lavas a elas associadas, de intrusões e o desenvolvimento de uma magmatismo fissural com caráter regional. A presença de rochas efusivas e fissurais básicas, volta a caracterizar a natureza profunda de parte das falhas e fraturas ativas nesta etapa.

Ao lado dos lineamentos são principalmente as estruturas antiformes de várias amplitudes e complexidades que controlam o alojamento dos granitóides, particularmente nas Faixas de Dobramento.

ASPECTOS GENÉTICOS A característica riqueza em granitóides, em ambas as Regiões de Dobramento aqui consideradas; o seu caráter ensiálico e aparente evolução "in situ", o número de fases de do- bramentos regionais presentes, o tipo de metamorfismo que nelas se instalou, a forte influência dos grandes lineamentos tectônicos, na distribuição e localização de grande parte dos complexos granitóides que exibem freqüentemente caráter polifásico (nos seus mais variados aspectos), devem ser considerados como feições básicas para a tentativa de uma interpretação genética sob aspecto geológico. Esta, entretanto, dado os poucos estudos de detalhes ora disponiveis terá, necessariamente, caráter amplo e algumas vezes especulativo.

O caráter polifásico de numerosos complexos sugere a existência de focos térmicos de atuação duradoura ou intermitente. A grande frequiência dos granitóides (em área e número de corpos) evidencia que os focos foram numerosos e de distribuição regional e indica, em função do caráter ensiálico das Regiões de Dobramento Nordeste e Sudeste, que a anatexia foi o processo genético mais importante. Tal fato é corroborado pelo metamorfismo de baixa a média pressão que agiu durante a etapa tecto-orogênica e pela espessura superior a $30 \mathrm{~km}$ determinado para parte da crosta siálica nas Regiões de Dobramento (Wernick e Gomes, 1976; Sartori, 1978). A importante influência dos grandes lineamentos tectônicos na distribuição e localização de grande parte dos complexos granitóides, aliada à sua natureza frequientemente profunda, denota que agiram decisivamente como canais térmicos (Ramberg, 1952, 1970) para o fluxo de calor e a ascenção dos magmas granitóides.

Tendo como pano de fundo este quadro geral, as diversas suites granitóides podem ser assim interpretadas:

A) Suite Sintectônica: A associação anatexítica, conforme as suas características descritas, resulta de anatexia parcial quer de rochas metassedimentares basais brasilianas, quer do embasamento pré-brasiliano. A natureza autóctona dos corpos, indica que não houve a produção de grandes quantidades de fundidos magmáticos, restritos a porções homofânicas diatexíticas, em rochas metatexíticas. A característica catazonal desta associação indica um nível crustal genético profundo. A sua freqüente localização em núcleos de estruturas antiformes revela o controle estrutural acentuado para o desenvolvimento da anatexia. Segundo Hasui e Sadowsky (1976) e Hasui et al. (1978-b) esta associação se formou durante a primeira fase de dobramento regional, pois sobre os corpos formados estão impressas deformações ligadas a uma fase posterior.

A associação Diorito-Granito Porfiróide resulta igualmente de uma anatexia em niveis catazonais. Neste caso, entretanto, a refusão e remobilização foi mais intensa, levando ao desenvolvimento de uma fase magmática móvel, hidratada (Associação TonalitoGranito) que ascendeu a niveis crustais superiores onde constitui corpos aloctones, quer nos Maciços Medianos quer nas Faixas de Dobramento. Os corpos 


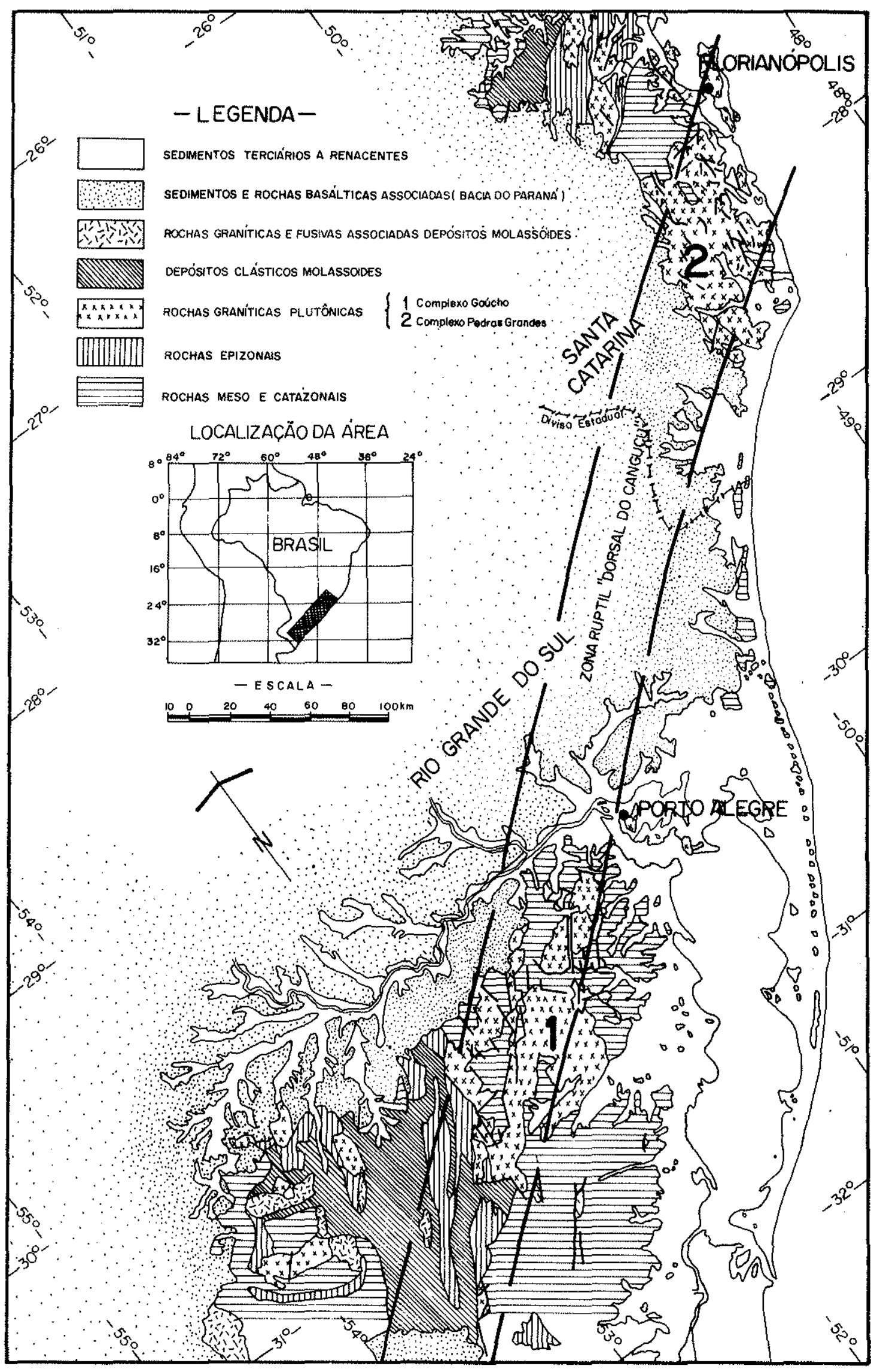

Figura 4 - Controle da penetração de complexos polidiapíricos ao longo de canais térmicos ligados à zonas rúpteis 


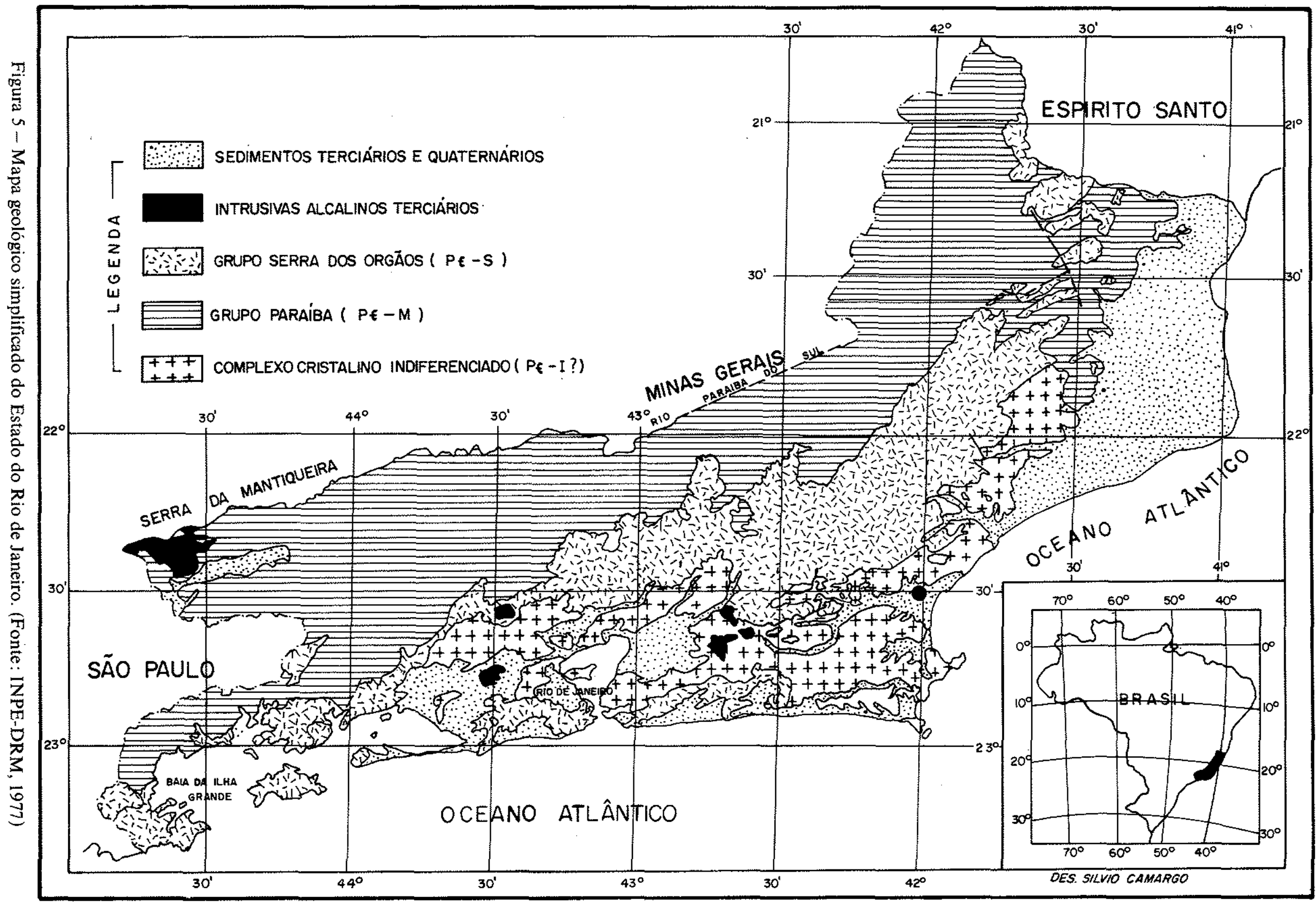




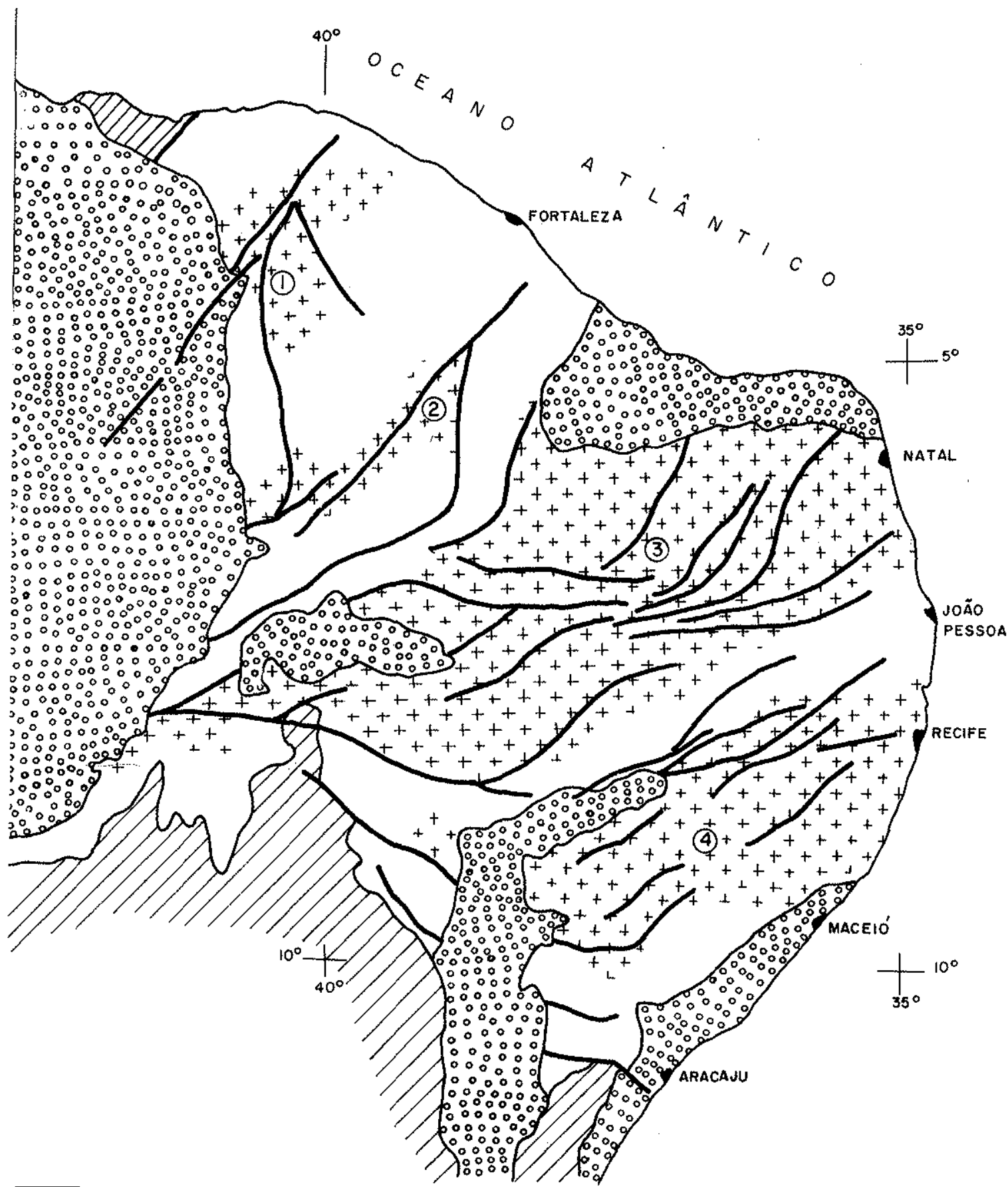

\%응 BACIAS SEDIMENTARES PÓS-BRASILIANAS

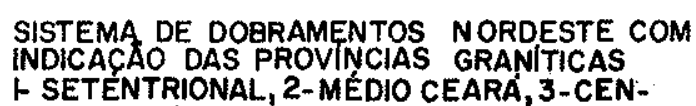

I SETENTRIONAL, 2-MÉDIO CEARA, 3-CEN-

TRAL E 4-MERIDIONAL

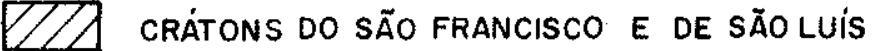

FALHAS

Figura 6 - Províncias graníticas brasilianas do Nordeste (segundo Santos e Melo, 1978) 
parautoctones e aloctones podem exibir diferenciações quer ao nível dos granitos porfiróides, quer originando massas granitóides equigranulares mais homogêneas e ácidas. $O$ processo anatectico foi acompanhado de intensa granitização que também afeta os corpos da Associação Anatexítica. Razões iniciais de isocronas $\mathrm{Rb} / \mathrm{Sr}$ da Associação de Raiz e da Associação Móvel, confirmam uma origem por retrabalhamento de material crustal e estudos em formas de cristais de zircão (Krebs et al., 1978) atestam que parte do material era de natureza sedimentar.

Santos e Mello (1978) correlacionam a suite sintectônica com a série de magmas hidratadas de Middlemost (1969). Neste sistema uma queda da pressão decorrente da ascensão dos corpos acarreta um aumento da pressão de $\mathrm{H}_{2} \mathrm{O}$, resultando numa cristalização parcial do magma, acompanhado da liberação de fluidos. Este processo continua até a cristalização total do magma, sendo que dos fluidos liberados, enriquecidos em $\mathrm{Si}, \mathrm{Na}$ e $K$, resulta a formação de pegmatitos, aplitos e veios de quartzo.

$\mathrm{A}$ introdução das fases mais móveis nas rochas granitóides pré-existentes provoca, nestas, remobilizações mais ou menos patentes aos quais se associam complexos fenômenos metassomáticos.

Para Hasui (1973); Hasui e Sadowsky (1976) e Hasui et al. (1978-b), a Associação de Raiz foi gerada na segunda fase regional de dobramentos. Sob este aspecto, é possível se entender que a Associação Móvel, geneticamente relacionada a mesma fase exiba, entretanto, toda gradação de características geológicas entre corpos sin- a pós-tectônicos, em função da maior ou menor rapidez na ascensão dos corpos e dos níveis crustais em que cristalizaram.

B) Suite Tarditectônica: Para as 3 associações tarditectônicas são propostos mecanismos genéticos variados. Já foi ressaltada a semelhança entre as Associações Tonalito-Granito sin- e tarditectônica, que correspondem possivelmente a mesma associação, sendo o caráter tarditectônico de parte dos corpos função do tempo de ascensão em relação à segunda fase de dobramento. De qualquer modo, a sua origem deve ser procurada em fenômenos anatecticos de grande profundidade. A ocorrência de granitos estaníferos que ocorrem na Associação Tonalito-Granito parecem suportar esta hipótese. Para a Associação Monzonito-Adamelito, ligada a zonas de ativo cisalhamento, Santos (1977) adota o modelo genético de Mc-Connel (1969), representado por uma anatexia sob o efeito de fricção em profundidade. A Associação Alcaligranitos-Sienitos tem sua origem em niveis crustais mais profundos que a Associação Monzonito-Adamelito.

Pessoa et al. (1978) advogam para esta suite o modelo genético de Thayer e Jakson (1972), que consiste numa geração parautoctone poligênica resultante da remobilização de material crustal de grande profundidade. Neste processo de cristalização poligênica, a fase final teria ocorrido sob significativa pressão de $\mathrm{H}_{2} \mathrm{O}$. A possivel presença de gabros alcalinos nesta associação, a presença de xenolitos da Associação Monzonito-Adamelito e razões iniciais de isocronas de $\mathrm{Rb} / \mathrm{Sr}$, parecem confirmar um nível crustal genético profundo.

O caráter hidratado e rico em voláteis desta associação propiciou vários tipos de diferenciações, o desenvolvimento de um amplo cortejo de rochas fissurais e fenômenos de greisenficação aos quais estão associados topázio, fluorita e turmalina.

C) Suite Pós-Tectônica: Tem uma origem muito profunda como atestam relações $\mathrm{Sr} / \mathrm{Rb}$ e razões iniciais de $\mathrm{Rb} / \mathrm{Sr}$ (Sartori, 1978). Esta origem deve ser procurada por anatexis dos niveis mais profundos da crosta siálica, junto à interfácie com o manto com possível contribuição de material juvenil ou mesmo por diferenciação direta de magmas juvenis do manto. O cortejo de rochas básicas efusivas e fissurais que acompanha esta suite, bem como o seu caráter freqüentemente anidro, são argumentos geológicos que parecem suportar tal interpretação. A heterogeneidade de vários dos corpos pós-tectônicos revelam que durante sua ascensão e cristalização ocorreram importantes fenômenos de assimilação, diferenciação e recristalização. A sua penetração em complexos granitóides pré-existentes, quer dos Maciços Medianos quer das Faixas de Dobramento, induz nestes fenômenos, mais ou menos patentes de remobilização, recristalização e metassomáticos. Para Santos e Mello (1978), a suite pós-tectônica pode ser enquadrada entre os granitos secos de Meddlemost (1969).

RESUMO E CONCLUSÓES A) As Regiões de Dobramento Nordeste e Sudeste foram geradas no Ciclo Brasiliano. São áreas geossinclinais de estruturação complexa, caráter ensiálico e evolução aparentemente "in situ". Sofreram metamorfismo de baixa a média pressão e são caracterizadas por intensa lineagênese em todas as suas etapas evolutivas.

B) As Regiões de Dobramento são caracterizạdas por um intenso magmatismo granitóide, quer em área quer em número, e tipos de corpos com caráter sin- tardi- e pós-tectônico situados no tempo, respectivamente entre $650 \pm 30$ m.a., $540 \pm 25$ m.a. e 510 a 460 m.a. Enquanto a fase tarditectônica se acha bem caracterizada na Região de Dobramento Nordeste, na Região de Dobramento Sudeste talvez seria preferivel se considerar uma fase de granitos sintectônicos e duas de granitóides pós-tectônicos, ơ uma gradação contínua entre as fases sin- e pós-tectônica.

C) A suite sintectônica inclui três associações: uma de Granitos Anatexíticos, autoctone, catazonal e associada preferencialmente a núcleos de estruturas antiformes e ligada à primeira fase de deformação; uma Diorito-Granito Porfiróide, autoctona-parautoctona catazonal e uma Tonalito-Granito, parautoctona-aloctona, móvel e predominantemente mesozonal. 
Esta associação mostra evidentes sinais de diferenciação. As duas últimas associações aparentemente estão geneticamente ligadas à segunda fase dẹ deformação regional. A suite tarditectônica inclui três associações: uma Tonalito-Granito cujo caráter tarditectônico é parcialmente questionável; uma Monzonito-Adamelito intimamente ligada a zonas de cisalhamento e uma de Alcaligranitos-Sienitos, possivelmente incluindo também termos mais básicos (gabros alcalinos). A suite pós-tectônica inclui rochas intrusivas calco-alcalinas, subalcalinas e alcalinas e manifestações efusivas e fissuras calco-alcalinas incluindo basaltos, andesitos; dácitos e riolitos.

D) Os complexos granitóides são, na maioria das vezes, polifásicos quer sob um ou mais aspecto (tectônico, posicionamento espacial, cronológico, estrutural, petrográfico, textural, ou químico).

E) É constatado um controle por meio de grandes alinhamentos tectônicos na distribuição e localização dos granitóides das diversas suites. A sua natureza, frequientemente profunda, é atestada por várias evidências geológicas.

F) As duas constatações precedentes indicam a existência de numerosos e amplos focos térmicos com atuação duradoura ou intermitente durante a etapa tecto-orogênica e de transição, tendo os lineamentos funcionados como canais térmicos ao longo dos quais ocorreram os fenômenos granitogênicos e a ascenção das diferentes gerações de massas granitóides, resultando em complexos polifásicos nos quais os mais jovens ou móveis induzem os mais antigos fenômenos mais ou menos intensos de remobilização, greisenficação, recristalização e metassomáticos.

G) A gênese das suites sin- e tarditectônicas está ligada a sucessivas etapas de anatexia com intensidade e em níveis crustais variáveis. A suite pós-tectônica tem origem por anatexia da crosta junto interfácie com o manto, com maior ou menor contribuição de material juvenil ou por cristalização fracionada de magmas básicos juvenis.

H) A suite sintectônica tem caráter essencialmente hidratado. A suite tarditectônica inclui associações provenientes de magmas anidros ou hidratados enquanto a suite pós-tectônica é de natureza essencialmente anidra. Ãs associações hidratadas estão vinculadas importantes recursos minerais, constituindo diversas províncias minerais com $\mathrm{Sn}, \mathrm{W}, \mathrm{Ta}, \mathrm{Be}, \mathrm{F}, \mathrm{Li}$, Mo, etc.

l) As características gerais do magmatismo acima delineado, coadunam-se com as descritas em outras áreas móveis ensiálicas (Muratov, 1968, 1977; Kuznetsov, 1974).

\section{BIBLIOGRAFIA}

ALMEIDA, F.F.M. de (1978) - A evolução dos cratons Amazônico e do São Francisco comparada com a de seus homólogos do Hemisfério Norte. An. XXX Congr. Bras. Geol., 6: 2393-2407, Recife.

ALMEIDA, F.F.M. de; LEONARDOS JR., O.H.; VALENÇA, J. (1967) - Granitic Rocks of Northeast South America, IUGS/UNESCO, $41 \mathrm{pp}$.

ALMEIDA, F.F.M. de; HASUI, Y. e BRITO NEVES, B.B. de (1967) - The Upper Precambrian of South America. Bol. Inst. Geoc. USP, 7: 45-80.

ALMEIDA, F.F.M. de; HASUI, Y.; RODRIGUES, E. de P. e YAMAMOTO, J. K. (1978) - A Faixa de Dobramento Araçuai na Região do Rio Pardo. An. XXX Congr. Bras. Geol., 1: 270-283, Recife.

AMARAL, F. (1974) - Geologia pré-cambriana da Região Amazônica. Tese: Inst. Geociências, USP, $212 \mathrm{pp}$.

BETTENCOURT, J.S.; WERNICK, E. e PENALVA, F. (1976) - Contribuição à metalogenia do Sistema de Dobramentos Ribeira. An. XXIX Congr. Bras. Geol., Ouro Preto (no prelo).

BRITO NEVES, B.B. de (1975)-Regionalização geotectônica do Pré-Cambriano Nordestino. Tese: Inst. Geociências, USP, São Paulo.

BRITO NEVES, B.B. de; CORDANI, U.G. (1973) - Problemas geocronológicos do "Geossinclinical Sergipano" e seu embasamento. An. XXVII Congr. Bras. Geol., 2! 67-76, Aracaju.

BRITO NEVES, B.B. de e PESSOA, R.J.R. (1974) - Consideraçōes sobre as rochas graníticas do Nordeste Oriental. An. XXVIII Congr. Bras. Geol. 6: 143-157, Porto Alegre.

BUDDINGTON, A.F. (1959)-Granite Emplacement with Special Reference to North America. Geol. Soc. Am. Bull., 70: 671-747.

CARRARO, C.C.; GAMERMANN, N.; EICK, N.C.; BORTOLUZZI, C.A.; JOST, H. e PINTO, J.F. (1974) - Mapa geológico do Estado do Rio Grande do Sul. Mapa do Inst. Geociências da UFRGS, 8: esc. 1:1.000.000, Porto Alegre.

CONDIE, K.C. (1973) - Archaean Magmatism and Crustal Thickening. Geol. Soc. of Am. Bull., 84: 2981-2992.

COUTINHO, J.M.V. (1971) - Estado atual de conhecimento do Pré-Cambriano Superior Sul Brasileiro: uma síntese. An. XXV Congr. Bras. Geol., 83-91. São Paulo. 
COUTINHO, J.M.Y. (1972) - Petrologia do Pré-Cambriano em São Paulo e arredores. Bol. Inst. Geoc. USP, 3: 5-19. São Paulo.

EBERT, H. (1969) - Geologia do Alto Seridó, Brasil/Sudene. Recife. 120 pp. (Série Geologia Regional, n. ${ }^{\circ} 11$ ).

ESKOLA, P. (1932) - On the origin of granite magmas. Mineral. Petrol. (N.F.), 42: 455-481.

FARINA, M. e MELLO, Z.F. de (1970) - Fenito com mineralização plumbo-cuprifera em Catingueira-Paraíba. Min. Met., Rio de Janeiro, 51 (306): 225-228.

FERREIRA, J.A.M. (1967) - Geologia da Quadrícula de Caicó, Folha E-062-Brasil/Sudene, Recife, 64 pp. (Série Geologia Regional n. 5).

FERREIRA, J.A.M.; ALBUQUERQUE, J.P.T. (1969) - Sinopse de Geologia da Folha Seridó-Brasil/Sudene. Recife. 52 pp. (Série Geologia Regional n. 18).

FUCK, R.A.; MARINI, O.J. e TREIN, E. (1967) - Contribuição ao estudo das rochas graníticas do Estado do Paraná, Bol. Paranaense Geociências, 23 a 25: 183-219.

GOMES, C.B. : RUBERTI, E. e WERNICK, E. (1976) - Caracterização química de feldspatos de rochas graniticas. An. Acad. Bras. Ciênc., 48 (3): 445-452.

GUIMARÃES, D. (1961) - Contribuição ao Estudo de Granitos Brasileiros. Inst. de Tecnologia Industrial, Bol. n. 27, 46 pp., Belo Horizonte.

HALL, A. (1971) - The Relationship between Geothermal Gradient and the Composition of Granitic Magmas in Orogenic Belts. Contr. Miner. and Petrol. 32: 186-192.

HASUl, Y. (1973) - Tectônica da área das Folhas de São Roque e Pilar do Sul. Tese: Inst. Geociênc. USP.

HASUI, Y. e HAMA, M. (1972) - Geocronologia do Grupo São Roque pelo método do potássio-argônico. Rev. Bras. Geoc., 2 (1): 18-24.

HASUI, Y. e SADOWSKY, G.R. (1976) - Evolução geológica do Pré-Cambriano da Região Sudeste do Estado de São Paulo. Rev. Bras. Geoc., 6 (3): 182-200.

HASUI, Y.; CARNEIRO, C.D.R. e COIMBRA, A.M. (1975) - The Ribeira Folded Belt. Rev. Bras. Geoc., 5 (4): 257-266.

HASUI, Y.; ALMEIDA, F.F.M. de e BRITO NEVES, B.B. de (1978a) - As estruturas Brasilianas. An. XXX Congr. Bras. Geol., 6: 2423-2435, Recife.

HASUI, Y.; CARNEIRO, C. dal R. e BISTRICHI, C.A. (1978-b) - Os granitos e granitóides da Região de Dobramento Sudeste nos Estados de São Paulo e Paraná. An. XXX Congr. Bras. Geol., 6: 2594-2608, Recife.

HÖGBOM, A. (1928) - On the relation between syntectonic granites and ore formation in Sweden. Fennia, $50(21): 1-14$.

HUMPHREY, F.L. e ALLARD, G.O. (1969) - Geologia da área do Domo de Itabaiana (Sergipe). Rio de Janeiro, CENPES/PETROBRÁS, $160 \mathrm{pp}$.

HUTCHISON, W.W. (1970)-Metamorphic framework and plutonic styles in the Prince Rupert region of the Central Coast Mountains, British Columbia. Can. Journ. Earth Sci., 376-405.

IUGS, Subcomission on the Systematics of Igneous Rocks (1973) - Classification and Nomenclature of Plutonic Rocks. Recommendations. N. Jb. Miner. Mh., H.4 Stuttgart, pp. 149-164.

JUNG, J. e ROQUES, M. (1938) - Les schistes cristallins du Massif Central français. Bull. Serv. Carte Géol. France, 39: 120-197, Paris.

KAUL, P.F.T. (1976) - Origem do granodiorito Valsungana no leste do Estado de. Santa Catarina. XXIX Congr. Bras. Geol., Bol. Esp. 1 (Resumo das Comunicações): 3.13, Belo Horizonte.

KREBS, A.; SOUZA, E.C. de e POMERANCBLUM, M. (1978)-Estudo preliminar de alguns zircões do granito Catinga, Leste de Santa Catarina. An. XXX Congr. Bras. Geol. 6: 2609-2623, Recife.

KUZNETSOV, Yu, A. (1971) - Principal types of magma-controlling structures and magmatic formations. Intern. Rev., 13 (11): 1585-1599.

LANDIM, P.M.B.: GOMES, C.B.: ARRUDA; J.R. e FULFARO, V.J. (1974) - Análise de agrupamento (cluster analysis) aplicada ao estudo geoquímico do granito Itaioca, região de Ribeira. An. XXVIII Congr. Bras. Geol. 3: 160-168, Porto Alegre.

MARMO, V. (1971) - Granite petrology and the granite problem. Developments in Petrology 2. Elsevier Publ. Co., 244 pp., il., Amsterdam.

MCCONNELL, R.B. (1969) - The association of granites with zones of stress and shearing. Geol. Soc. Am. Bull., 80: 115-120.

MELCHER, G.C.; GOMES, C.B.; CORDANI, U.G.; BETTENCOURT, J.S.; DAMASCENO, E.C.; GIRARDI, V.A.V. e MELFI, A.J. (1973) - Geologia e Petrologia das rochas metamórficas e graníticas associadas do Vale do Rio Ribeira de Iguape, SP e PR. Rev. Bras. Geoc., 11 (2): 97-123. 
MELLO, A.A. de (1971) - Geologia e Petrologia da região de Fazenda Nova, Pernambuco. Tese: Inst. Geociências, USP.

MELLO, A.A. de; SOUZA, E.M. de e MENDONÇA, J.C.G. (1978) - A tectônica linear no Estado do Ceará. An XXX Congr. Bras. Geol., 1: 393-407, Recife.

MELLO, Z.F. (1978) - Evoluções finais do Ciclo Geotectônico Brasiliano no Nordeste Oriental. An. XXX Congr. Bras. Geol., 6: 2438-2450, Recife.

MIDDLEMOST, E.A.K. (1969) - The granitic spectrum. Lithos, 2 (3): 217-222.

MURATOV, M.V. (1968) - Geosynclinal Folded Belts and Systems Stages of Development and Igneous Activity. Intern. Geol. Rev., 10 (12): 1386-1399.

MURATOV, M.V. (1974) - Structure and development of median masifs in geosynclinal folded region. Geotectonic, 3: 142-146.

MURATOV, M.V. (1977) - The origin of continents and ocean basins. Mir Publishers, Moscou (Tradução por V. Agranat).

NOCKOLDS, S.R. (1954) - Average Chemical Composition of Some Igneous Rocks. Geol. Soc. Am. Bull., 65: 1007-1032.

PESSOA, R.R. (1972) - Um exemplo de granitização em rocha básica do Nordeste Brasileiro. XXVI Congr. Bras. Geol., Bol. Esp. 1 (Resumo das Comunicações): 203-204, Belém.

PESSOA, R.R. (1974) - Considerações sobre a mineralogênese pré-cambriana no Nordeste oriental brasileiro. An. XXVIII Congr. Bras. Geol., 3: 2-9. Porto Alegre.

PESSOA, R.R.; PESSOA, D.R.; BRITO NEVES, B.B. de (1978)-Magmatismo tarditectônico Brasiliano no Maciço Pernambuco-Alagoas: o quartzo sienito de Cachoeirinha, PE. An. XXX Congr. Bras. Geol., 3: 1279-1287, Recife.

PICADA, R.S. (1967) - Estudos preliminares sobre a evolução geoquímica e mineralógica do Maciço Granítico Encruzilhada. Publ. Esp. Esc. Geol. UFRGS, 14: 1-87, Porto Alegre.

RAGUIM, E. (1957) - Géologie du Granite Masson. 275 pp. il., Paris.

RAMBERG, H. (1952) - The origin of metamorphic and metasomatic rocks. The University of Chicago Press.

RAMBERG, H. (1970)-Model studies in relation to intrusion of plutonic bodies. In "Mechanism of Igneous Intrusion". (Ed. G. Newall e N. Rast), Gallery Press, Liverpool: 261-286.

READ, H.H. (1949) - A contemplation of time plutonism. In The granite controversy. Thomas Murby \& Co.: 263-338, Londres.

RIBEIRO, M.; LICHTENBERG, E. (1978) - Sintese da geologia do Escudo do Rio Grande do Sul. An. XXX Congr. Bras. Geol., 6: 2451-2463, Recife.

RIDEG, P. (1974) - Geology and structure of a portion of the Serra do Mar in Eastern São Paulo, Brazil. State University of New York at Binghanton, Tese de Doutoramento, 145 pp., il. mapa.

ROQUES, M. (1941) - Les schistes cristallins de la partie SO du Massif Central français. Mém. pour servir a l'Explication de la Carte Gèol. détaillée de la France, 1: 1-527.

SÃ, J.H. da SILVA (1977) - Pegmatitos litiníferos da região de Itinga-Araçuaí, Minas Gerais. Tese: Inst. Geoc., USP.

SADOWSKY, G.R. (1975) - O batólito quartzo-sienítico da Serra da Baixa Verde, Pernambuco. Boletim IG, Inst. Geoc., USP, 4: 39-46.

SADOWSKY, G.R. (1974) - Tectônica da Serra de Cubatão, SP. Tese: Inst. Geoc., USP.

SANTOS, E.J. dos (1968) - Contribuição ao Estudo da Geologia da Quadrícula de Açu, Recife. Sudene, 116 pp. il. (Brasil, SUDENE, Série Geologia Regional, n. ${ }^{\circ}$ 6).

SANTOS, E.J. dos (1969) - O modo de evolução de alguns migmatitos dos arredores de Belém e Brejo da Cruz, Paraíba. Recife, SUDENE, 40 pp. il (Brasil, SUDENE, Série Especial, n ${ }^{\circ}{ }^{8}$ ).

SANTOS, E.J. dos (1971) - As feições estruturais da Folha Arcoverde, Pernambuco e o mecanismo dos falhamentos da Zona Transversal. Mineração Metalúrgica, Rio de Janeiro, 53 (313): 35-40.

SANTOS, E.J. dos (1973) - Província Scheelitífera do Nordeste. In: Congresso Brasileiro de Geologia, 27, Aracaju, Soc. Bras. Geol., pp. 31-46, (Boletim, 3).

SANTOS, E.J. dos (1977) - O modelo de evolução precambriana da região de Arcoverde, Pernambuco. Campina Grande, Simpósio Geol. Nordeste, 20 pp. (em impressão).

SANTOS, E.J. dos e VASCONCELOS, M.L. (1973) - Características dos granitóides do tipo Moderna do lineamento Pernambuco. Min. Met. Rio de Janeiro, 36 (339): 28-33.

SANTOS, E.J. dos e SILVA F. ${ }^{\circ}$, M.A. da (1975) - Ensaio interpretativo sobre a evolução da geossinclinal de Propriá, Nordeste do Brasil. Min. Met. Rio de Janeiro, 39 (367): 3-22.

SANTOS, E.J. dos e VASCONCELOS, M.L. (1977) - Plutonismo granítico nos arredores de Sítio dos Nunes, Pernambuco e seu significado no contexto da granitização brasiliana do Nordeste. Rev. Bras. Geoc., 7 (1): 58-72, São Paulo. 
SANTOS, J.E. dos e MELO, C.B.M. (1978) - Diversidade do plutonismo granítico Brasiliano do Nordeste. An. XXX Congr. Bras. Geol. 6: 2624-2634, Recife.

SARTORI, P.L.P. (1978)-Petrologia do Complexo Granítico de São Sepé, RS: modelo evolucional de granitos do Sul do Brasil. Tese: Inst. Geociências, USP.

SEDERHOLM, J.J. (1928) - On graniterna i Sverige och Finland. Geol. Fören. Stockholm Förk., 50: 45-89.

SCHEUMANN，K.H. (1924) - Prävariskische Glieder der Ächsisch-Fichtelgebirgischen Kristallinen Schifer. I - Die magmatisch orogenitische Stellung der Frankberger Gneisgesteine Abh. Math. Phys. Kl. Säcks. Ak. Wiss., 39 (1): 1-61.

SIAL, A.N. (1978) - Os corpos graníticos da Meruoca e de Mucambo, Sobral, Ceará. XXX Congr. Bras. Geol., Bol. Esp. 1 (Resumo das Comunicações): 309-310, Recife.

SILVA FILHO, M.A. da; BOMFIM, L.F.C. e SANTOS, R.A. dos (1978) - A Geossinclinal Sergipana: estratigrafia, estrutura e evolução. An. XXX Congr. Bras. Gdol., 6: 2464-2477, Recife.

SIMONEN, A. (1960) - Plutonic rocks of the Svecofennides in Finland. Bull. Comm. Geol. Finland, 189: 1-101.

SKVÓR, U. (1967) - The relation of metallogeny do deepseated faults and granitoids massifs. Proc. Symp. Probl. Hydrothermal Ore Deposits. Ser. A, 2: 82-84, St. Andrews, Scotland.

SMULIKOWSKI, K. (1958) - Problem of Genetic Classification of Granitoids - Studia Geol. Polon., 1, pp. 59-115.

STEPHANSSON, O. (1975) - Polydiapirism of granitic rocks in the Svecofennian of Central Sweden. Precambrian Research 2 (2): 189-214, Amsterdam.

THAYER, T.P.; JACKSON, E.D. (1972) - A Classification of Igneous Rocks by their History of Crystallization and Emplacement. U.S. Geol. Survey Prof. Paper 800-B.: 879-883.

TUTTLE, O.F. e BOWEN, N.L. (1958) - Origin of granite in the light of experimental studies in the system $\mathrm{NaAlSiO}_{3} \mathrm{O}_{8}-\mathrm{KAlSi}_{3} \mathrm{O}_{8}-\mathrm{SiO}_{2}-\mathrm{H}_{2} \mathrm{O}$. Mem. Geol. Am. 74: 1-153.

USTIYEV, Y.K. (1970) - Volcanic, subvolcanic and plutonic series of the Northeastern Asia and the general problem of the volcano-plutonic formations. Bull. Volcanol. 33 (4): 1274$-1287$.

VANDOROS, P. e COUTINHO, J.M.V. (1966) - Estudo geológico e geocronológico da área de São Gonçalo, Paraíba. Bol. Soc. Bras. Geol., 15 (4): 15-26, São Paulo.

WAHL, W.W. (1936) - The granites of the Finnish part of the Svecofennian Arachaean mountain chain. Bull. Comm. Geol. Finland, 115: 489-505.

WERNICK, E. (1972-a) - A geologia do maciço granítico de Morugaba, leste do Estado de São Paulo. Esc. Eng. São Carlos, USP, Bol. Geol., 16: 1-110.

WERNICK, E. (1972-b) - Granitos pórfiros dos arredores da Serra Negra, Valinhos e Amparo e suas relações com o maciço de Morungaba, leste do Estado de São Paulo. Rev. Bras. Geoc., 2 (2): 129-138.

WERNICK, E. (1978) - Cristalização fracionada na Província Ribeira, SP e PR. XXX Congr. Bras. Geol., Bol. Esp. 1 (Resumo das Comunicações): 316, Recife.

WERNICK, E. e GOMES, C.B. (1976) - Granitos e metamorfismo no vale do Ribeira de Iguape, SP e PR. An. XVIII Congr. Bras. Geol. 5: 145-154, Porto Alegre.

WERNICK, E. e GOMES, C.B. (1977) - Geoquímica de maciços graníticos da região do Ribeira. Parte III: Considerações Petrológicas. An. Acad. Bras. Ciênc. 49 (1): 157-169.

WERNICK, E. e PENALVA, F. (1974) - Migmatização e feldspatização de charnockitos e granulitos no leste paulista e sul de Minas Gerais. An. XXVIII Congr. Bras. Geol., 5: 155-160, Porto Alegre.

WERNICK, E. e PENALVA, F. (1978-a) - Contribuição ao conhecimento das rochas granitóides do sul do Brasil. Rev. Bras. Geoc. 8 (3): 113-133.

WERNICK, E. e PENALVA, F. (1978-b) - O Grupo Pinhal na Região Nordeste do Estado de São Paulo e áreas vizinhas do Estado de Minas Gerais. XXX Congr. Bras. Geol., Bol. Esp. 1 (Resumo das Comunicações): 315-316, Recife.

WERNICK, E.; PANTOJA, J.L. e NICOLA, J.P. (1976)-Megacristais do Maciço Granítico de Socorro (SP e MG). Soc. Bras. Geol. (Núcleo de Minas Gerais), Bol. Esp. 1 (Resumo das Comunicações): 329, Belo Horizonte.

WERNICK, E.; HASUI, Y. e BRITO NEVES, B.B. de (1978) - As Regiões de Dobramento Nordeste e Sudeste. An. XXX Congr. Bras. Geol., 6: 2493-3507, Recife.

ZARIDZE, G.M. (1975) - Formation of granitoids in relation to tectonic structures. Krystalinikum, 11: 115-122. 